\title{
Multisystem inflammatory syndrome in an adult after SARS-CoV-2 infection
}

\author{
Geneviève Kerkerian MD, Stephen D. Vaughan MD
}

— Cite as: CMAJ 2021 June 21;193:E956-61. doi: 10.1503/cmaj.210232

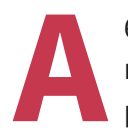

60-year-old man presented to the emergency department with a 5-day history of mild shortness of breath, profound fatigue, anorexia and fever of up to $40^{\circ} \mathrm{C}$. He also reported a lymph node enlargement over the left side of his neck, which had resolved 2 days before presentation. Four weeks earlier, he had tested positive for SARS-CoV-2 infection, confirmed by polymerase chain reaction (PCR) testing. He had no known comorbidities and had not received vaccination against SARS-CoV-2.

The patient's heart rate was 150 beats/min, with new-onset atrial fibrillation. His blood pressure was $106 / 67 \mathrm{~mm} \mathrm{Hg}$ and his oxygen saturation on room air was normal. His respiratory examination showed good air entry bilaterally, without crepitus, crackles or wheezing on auscultation. He had bilateral nonpurulent conjunctivitis (Figure 1A), erythema and enlargement of his tongue (Figure 1B), bilateral pitting edema, and erythema of the distal portion of his toes bilaterally (Figure 1C). Lesions were not associated with any vesicles, erosive features, crusting, fissures, warmth, swelling or tenderness. A chest radiograph showed right

\section{KEY POINTS}

- Multisystem inflammatory syndrome is an uncommon but severe complication primarily described in children and adolescents after infection with SARS-CoV-2; it can also occur in older individuals.

- After recovery from SARS-CoV-2 infection, clinicians should suspect multisystem inflammatory syndrome in adults when a patient has prolonged fever, with multiorgan involvement.

- Elevated inflammatory markers support the diagnosis.

- Prompt initiation of therapy with immunomodulatory treatment can prevent severe outcomes.

lower lobe opacification. An electrocardiogram showed atrial fibrillation with rapid ventricular response, as well as nonspecific diffuse ST-T wave abnormality (Figure 2). Computed tomography (CT) of the patient's chest with contrast was negative for pulmonary embolism, but showed right heart enlargement and early pulmonary edema.

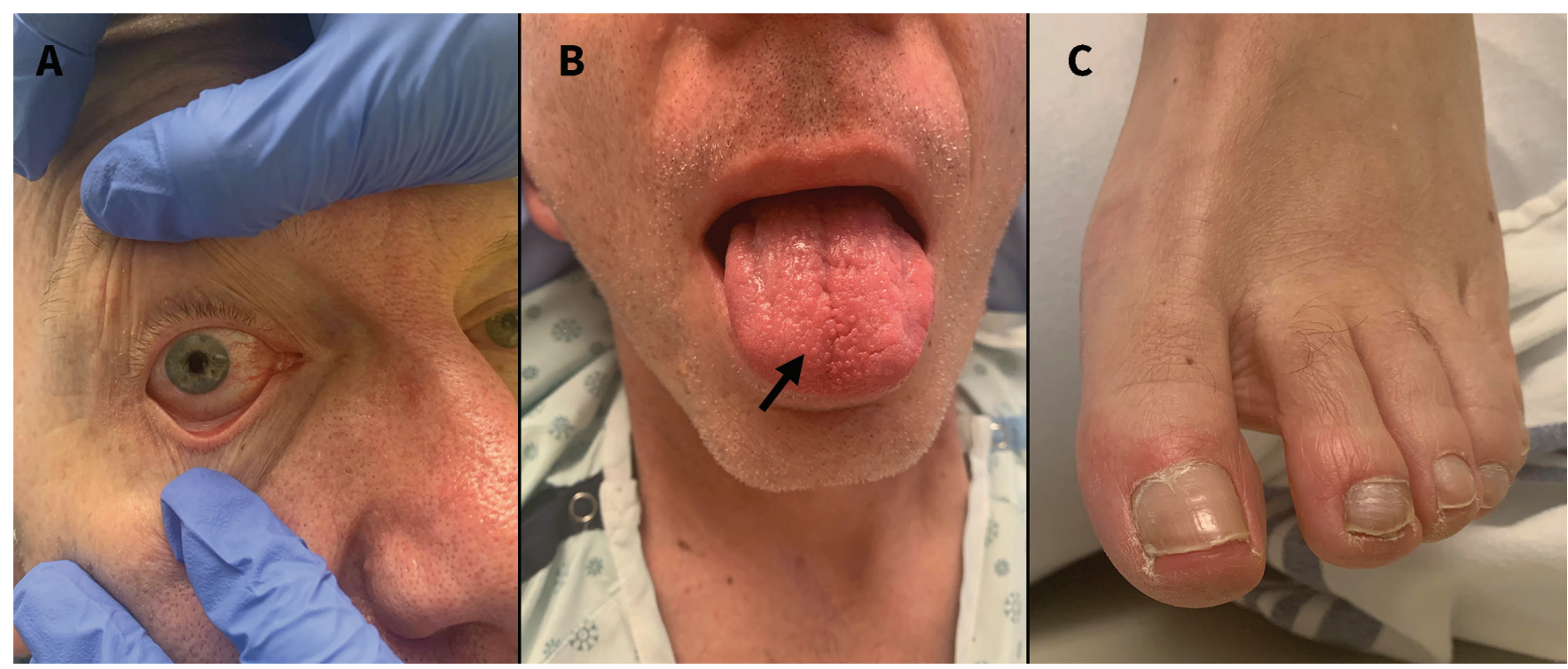

Figure 1: (A) Nonpurulent bilateral conjunctivitis in a 60-year-old man (only right eye shown). (B) Glossitis manifesting as nontender diffuse erythema and symmetric enlargement of the tongue. Small enanthem of the anterior third of the dorsum of the tongue (small erythematous bumps [arrow]) with hyperplastic fungiform and filiform papillae. (C) Left toes showing nonblanching maculopapular erythema. All images were taken before treatment was started. 


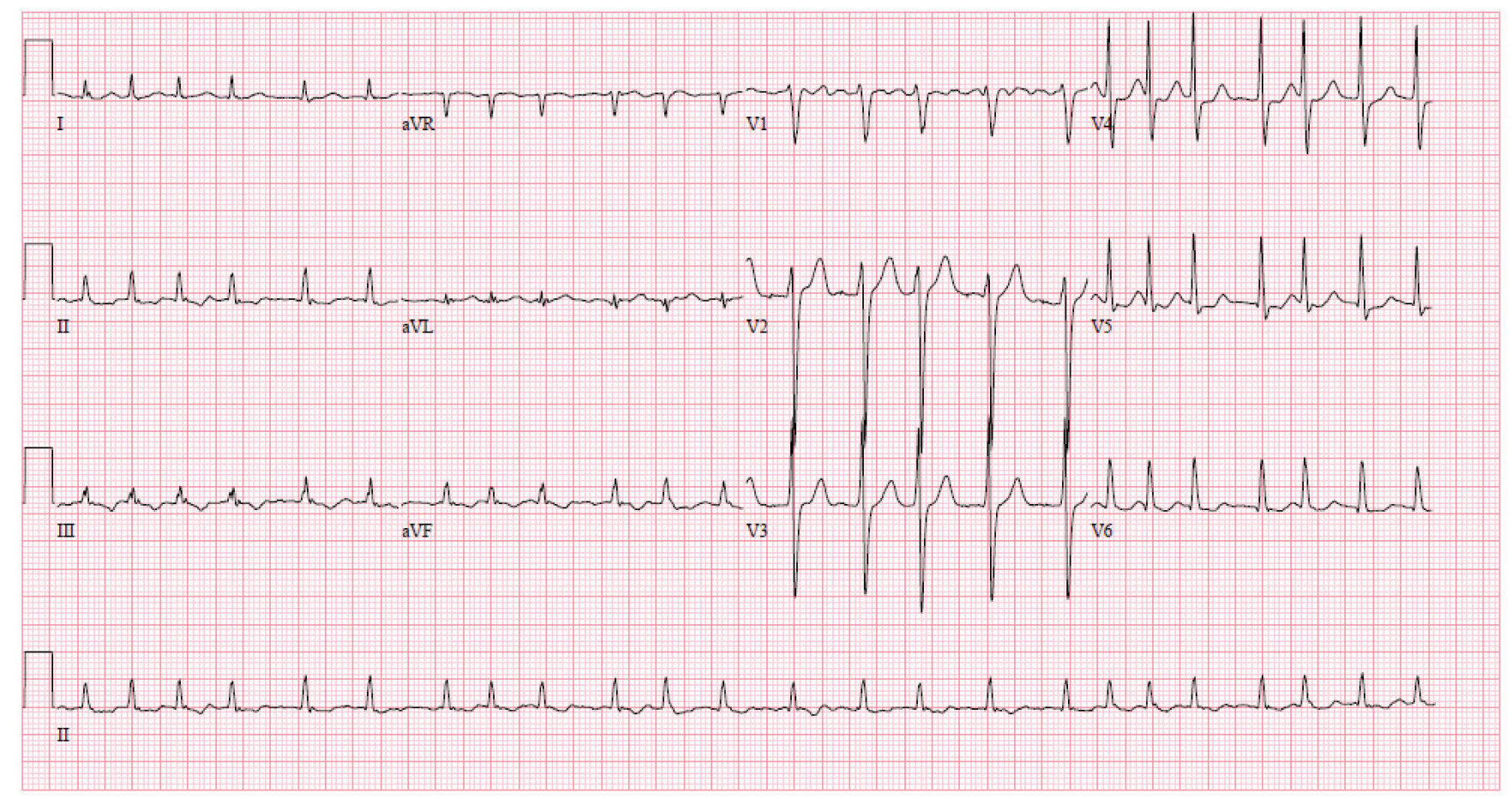

Figure 2: Electrocardiogram showing ventricular rate of 143 beats/min, atrial fibrillation with rapid ventricular response and diffuse nonspecific ST-T wave abnormality.

The patient was admitted and started on empirical piperacillintazobactam for possible bacterial pneumonia as a superinfection of his previous SARS-CoV-2 infection. Initial laboratory workup was notable for elevated C-reactive protein, D dimer, ferritin and leukocytosis with neutrophilia (Table $1^{1}$ ), indicating acute inflammation. His troponin level was elevated, and he had a substantially elevated pro-brain-type natriuretic peptide level. Blood cultures, urine culture and a respiratory viral panel were drawn and later returned negative. The patient also tested negative for HIV and hepatitis C and was immune to hepatitis B. An autoimmune workup collected before initiation of therapy was negative. COVID-19 immunoglobulin G serology was positive. A transthoracic echocardiogram, done after initiation of corticosteroids, showed normal sinus rhythm and normal right and left ventricular systolic and diastolic function with mild to moderate mitral regurgitation. There were no previous echocardiogram studies with which to compare these findings.

Given the patient's recent history of SARS-CoV-2 infection, fevers without localizing symptoms, oral mucosal changes, cervical lymphadenopathy, conjunctivitis and lower extremity changes, we suspected inflammatory post-COVID-19 syndrome. The presentation was similar to reported cases of an uncommon but severe complication in children and adolescents infected with SARS-CoV-2, called multisystem inflammatory syndrome in children (MIS-C), as well as to Kawasaki-like illness (Table $2^{2-4}$ ). Both the pediatric and adult rheumatology teams involved in the patient's care agreed that he met the preliminary Centers for Disease Control and Prevention (CDC) criteria for multisystem inflammatory syndrome in adults (MIS-A) and the criteria for complete Kawasaki disease, and he had multiple features consistent with MIS-C.
We started the patient on acetylsalicylic acid (ASA) and methylprednisolone and discontinued antibiotics. The next day, he received intravenous (IV) immunoglobulin. Within 24 hours of beginning treatment, he reported substantial improvement in his level of energy, shortness of breath and anorexia, with documented resolution of fever, improved conjunctivitis (Figure $3 \mathrm{~A}$ ), and decreased erythema of his tongue (Figure $3 \mathrm{~B}$ ), as well as reduction in inflammatory markers (Table 1). Repeat electrocardiogram was normal (Figure 4). The patient was discharged home 5 days after admission. Fourteen days after discharge, and again at a 6-week follow-up, he continued to improve clinically and biochemically (Table 1).

\section{Discussion}

Since the beginning of the SARS-CoV-2 pandemic, new information has been emerging on the trajectory of the disease. Examples of complications include venous thromboembolism, cardiovascular disease, acute kidney or liver injury, neurologic symptoms and post-COVID-19 syndrome. ${ }^{5}$ Multisystem inflammatory syndrome in children was first described in April 2020 as a hyperinflammatory syndrome with features resembling Kawasaki disease. ${ }^{2,3,6}$ As of May 3, 2021, 3742 children in the United States had been formally diagnosed with MIS-C according to the criteria outlined in Table 2, with 35 related deaths. ${ }^{7}$

In October 2020, the CDC published a review of 27 adult cases that fit the description of a multisystem inflammatory syndrome. ${ }^{4}$ The preliminary case definition of MIS-A is shown in Table 2, and cases described to date have been in patients younger than 50 years. As we continue to learn about MIS-A, however, it is prudent not to assume any age limitation when considering the diagnosis, as our case suggests., ${ }^{4,-10}$ 
Table 1: Laboratory data for 60-year-old man with multisystem inflammatory syndrome after SARS-CoV-2 infection *

\begin{tabular}{|c|c|c|c|c|c|c|c|c|}
\hline Laboratory value & $\begin{array}{c}\text { On } \\
\text { admission }\end{array}$ & $\begin{array}{l}\text { Day } 1 \text { after } \\
\text { steroids }\end{array}$ & $\begin{array}{l}\text { Day } 2 \text { after } \\
\text { steroids, } \\
\text { day } 1 \text { IVIG }\end{array}$ & $\begin{array}{c}\text { Day } 3 \\
\text { steroids, } \\
\text { day } 2 \text { IVIG, } \\
\text { discharge day }\end{array}$ & $\begin{array}{l}6 \text { wk after } \\
\text { discharge }\end{array}$ & $\begin{array}{l}12 \text { wk after } \\
\text { discharge }\end{array}$ & $\begin{array}{l}16 \text { wk after } \\
\text { discharge }\end{array}$ & $\begin{array}{l}\text { Reference } \\
\text { range }\end{array}$ \\
\hline \multicolumn{9}{|l|}{ Hematology and chemistry } \\
\hline C-reactive protein (mg/L) & 274.7 & & 71.6 & 35.1 & $<0.6$ & $<0.6$ & 1.5 & $0.0-8.0$ \\
\hline Ferritin (ug/L) & 888 & & 731 & 715 & 154 & 82 & 58 & $300-500$ \\
\hline D dimer (mg/LFEU) & 2.14 & & 1.07 & 1.01 & 0.81 & 0.61 & 0.58 & $<0.50$ \\
\hline INR & 1.3 & & & 1.3 & & & & $0.9-1.1$ \\
\hline Leukocytes $\left(10^{9} / \mathrm{L}\right)$ & 16.2 & 15.0 & 18.6 & 8.0 & 4.1 & 4.3 & 4.1 & $4.0-11.0$ \\
\hline Neutrophils $\left(10^{9} / \mathrm{L}\right)$ & 14.0 & 13.3 & 16.7 & 6.2 & 1.9 & 2.0 & & $2.0-8.0$ \\
\hline Platelet count $\left(10^{9} / \mathrm{L}\right)$ & 248 & 375 & 505 & 464 & 202 & 218 & 179 & $150-400$ \\
\hline Lymphocytes $\left(10^{9} / \mathrm{L}\right)$ & 0.9 & 0.8 & 0.6 & 0.9 & 1.8 & 1.8 & & $0.7-3.5$ \\
\hline Hemoglobin (g/L) & 133 & 125 & 120 & 116 & 154 & 151 & 156 & $137-180$ \\
\hline Mean corpuscular vol. (fL) & 93 & 92 & 93 & 93 & 96 & 96 & & $82-100$ \\
\hline Triglycerides (mmol/L) & & & 2.11 & & 1.65 & 1.50 & 1.67 & $0.00-1.70$ \\
\hline $\operatorname{ALT}(\mathrm{U} / \mathrm{L})$ & 41 & & & & 14 & 9 & 8 & $8-40$ \\
\hline Creatinine level $(\mu \mathrm{mol} / \mathrm{L})$ & 97 & 78 & 84 & 82 & 78 & 73 & 74 & $50-120$ \\
\hline Troponin (ng/L) & 38 & & & & & & & $0-13$ \\
\hline NT-pro BNT (ng/L) & 2840 & & & & 70 & 63 & $<50$ & $0-300$ \\
\hline Lactate (mmol/L) & 2.2 & & & & & & & $0.5-2.2$ \\
\hline Creatine kinase $(\mathrm{U} / \mathrm{L})$ & 29 & & & & & & & 0-195 \\
\hline Lipase (U/L) & 17 & & & & & & & $0-80$ \\
\hline Lactate dehydrogenase (U/L) & 199 & & & & & & & $100-235$ \\
\hline Alkaline phosphatase (U/L) & 128 & & & & & & & 30-145 \\
\hline Bilirubin total ( $\mu \mathrm{mol} / \mathrm{L})$ & 15 & & & & & & & $0-24$ \\
\hline Glucose (random) (mmol/L) & 7.1 & & & & & & & $3.3-11.0$ \\
\hline \multicolumn{9}{|l|}{ Urine analysis } \\
\hline Leukocytes & Trace & & & & & & & Negative \\
\hline Nitrites & Negative & & & & & & & Negative \\
\hline Protein & Negative & & & & & & & Negative \\
\hline Glucose & Negative & & & & & & & Negative \\
\hline Ketones & Negative & & & & & & & Negative \\
\hline Blood & Trace & & & & & & & Negative \\
\hline Leukocytes & $6-10$ & & & & & & & 0-5/hpf \\
\hline Epithelial cells & Moderate & & & & & & & /hpfø \\
\hline Hyaline cast & $5-10$ & & & & & & & $/ / \mathrm{pf} \|$ \\
\hline \multicolumn{9}{|l|}{ Microbiology data } \\
\hline Blood cultures & Negative $\times 2$ & & & & & & & Negative \\
\hline Urine culture & Negative & & & & & & & Negative \\
\hline COVID-19 NAT $\dagger$ & $\begin{array}{l}\text { Negative and } \\
\text { positive }^{\star \star}\end{array}$ & Negative & & & & & & Negative \\
\hline COVID-19 serology $\ddagger$ & Positive & & & & & & & Negative \\
\hline Respiratory infection panel§ & Negative & & & & & & & Negative \\
\hline HIV serology & Negative & & & & & & & Negative \\
\hline Hepatitis $\mathrm{C}$ antibody & Negative & & & & & & & Negative \\
\hline
\end{tabular}

Note: $\mathrm{ALT}=$ alanine aminotransferase, $\mathrm{FEU}=$ fibrinogen-equivalent units, $\mathrm{hpf}=$ high power field, INR = international normalized ratio, IVIG = intravenous immunoglobulin, Ipf = low power field, NAT = nucleic acid amplification, NT pro-BNP = N-terminal pro-brain-type natriuretic peptide.

*Bolded values show abnormal results.

†All COVID-19 NAT were on nasopharyngeal swabs.

łImmunoglobulin G serology testing.

§Respiratory infection panel tests for influenza (A and B), parainfluenza virus (1, 2, 3, 4), human coronaviruses (229E, NL63, OC43, HKU1), metapneumovirus, enterovirus, rhinovirus and adenovirus. INo reference range, as normally not seen.

${ }^{\star \star}$ The patient had testing done as an outpatient on the day of admission (negative results) and then again when he went to the emergency department (positive results). For the positive nasopharyngeal swab, the cycle threshold value was 36 (very high), and insufficient for sequencing the spike protein and whole-genome sequencing. A higher cycle threshold value correlates with lower viral load ${ }^{1}$ and the repeat nasopharyngeal swab the next day came back negative. This likely suggests that the positive result was from residual RNA from the previous SARS-CoV-2 infection 4 weeks earlier, rather than reinfection or persistent infection. 
Table 2: CDC criteria for multisystem inflammatory syndrome in adults and children with SARS-CoV-2 infection and Kawasaki disease $^{2-4}$

\begin{tabular}{|c|c|c|c|}
\hline Characteristic & $\begin{array}{l}\text { Multisystem inflammatory } \\
\text { syndrome in adults }\end{array}$ & $\begin{array}{l}\text { Multisystem inflammatory } \\
\text { syndrome in children }\end{array}$ & Kawasaki disease \\
\hline Case definition & $\begin{array}{l}\text { Hospital admission of a patient } \\
\text { aged } \geq 21 \text { yr without evidence } \\
\text { of severe respiratory illness and } \\
\text { no alternative plausible } \\
\text { diagnosis and involvement of } 1 \\
\text { or more extrapulmonary organ } \\
\text { systems: } \\
\text { - Hypotension or shock } \\
\text { - Cardiac dysfunction } \\
\text { - Arterial or venous } \\
\text { thromboembolism } \\
\text { - Acute liver injury } \\
\text { and laboratory evidence of } \\
\text { acute inflammation }\end{array}$ & $\begin{array}{l}\text { Patient aged }<21 \text { yr with fevers } \\
>38.0^{\circ} \mathrm{C} \text { for } \geq 24 \mathrm{~h} \text {, or report of } \\
\text { subjective fever lasting } \geq 24 \mathrm{~h} \text { with } \\
\text { laboratory evidence of clinically } \\
\text { severe illness requiring hospital } \\
\text { admission with multisystem }(\geq 2) \\
\text { organ involvement: } \\
\text { - Cardiac } \\
\text { - Renal } \\
\text { - Respiratory } \\
\text { - Hematologic } \\
\text { - Gastrointestinal } \\
\text { - Dermatologic } \\
\text { - Neurologic }\end{array}$ & $\begin{array}{l}\text { Complete Kawasaki disease: } \\
\text { Fevers } \geq 5 \mathrm{~d} \\
\text { AND } \geq 4 \text { principal clinical features } \\
\text { - Extremity changes* } \\
\text { - Rash } † \\
\text { - Conjunctivitis } ¥ \\
\text { - Oral changes§ } \\
\text { - Cervical lymphadenopathy (at least } 1.5 \mathrm{~cm} \text { in } \\
\text { diameter, usually unilateral) } \\
\text { Suspected incomplete Kawasaki disease: } \\
\text { Fevers } \geq 5 \mathrm{~d} \\
\text { AND } \\
2-3 \text { compatible clinical criteria, or infants with } \\
\text { fevers } \geq 7 \mathrm{~d} \text { without other explanation. }\end{array}$ \\
\hline $\begin{array}{l}\text { Supportive } \\
\text { investigations and } \\
\text { laboratory finding }\end{array}$ & $\begin{array}{l}\text { Elevated CRP, ferritin, D dimer } \\
\text { or IL-6 }\end{array}$ & $\begin{array}{l}\text { Elevated CRP, ESR, fibrinogen, } \\
\text { procalcitonin, D dimer, ferritin, } \\
\text { lactate dehydrogenase or IL-6, } \\
\text { elevated neutrophils, reduced } \\
\text { lymphocytes and low albumin }\end{array}$ & $\begin{array}{l}\text { CRP } \geq 3.0 \mathrm{mg} / \mathrm{dL} \\
\text { (or) } E S R \geq 40 \mathrm{~mm} / \mathrm{hr} \\
\text { AND } \\
\text { 1) Positive echocardiogram: From AHA criteria, }{ }^{2} \\
\text { echocardiography is considered positive if any } \\
\text { of } 3 \text { conditions are met: } \\
\text { - } Z \text { score of left anterior descending coronary } \\
\text { artery or right coronary artery } \geq 2.5 \text {; coronary } \\
\text { artery aneurysm is observed; or } \geq 3 \text { other } \\
\text { suggestive features exist, including decreased } \\
\text { left ventricular function, mitral regurgitation, } \\
\text { pericardial effusion } \\
\text { - or } Z \text { scores in left anterior descending } \\
\text { coronary artery } \\
\text { - or right coronary artery of } 2-2.5 \\
\text { OR } \\
\text { 2) } \geq 3 \text { supportive laboratory findings (anemia for } \\
\text { age, platelet count } \geq 450000 \text { after } 7 \text { th day of } \\
\text { fevers, albumin } \leq 3.0 \mathrm{~g} / \mathrm{dL} \text {, elevated alanine } \\
\text { aminotransferase, leukocytes } \geq 15000 / \mathrm{mm}^{3} \text {, or } \\
\text { urine with } \geq 10 \text { leukocyte/hpf) }\end{array}$ \\
\hline SARS-CoV-2 & $\begin{array}{l}\text { Positive for current or previous } \\
\text { SARS-CoV-2 infection (nucleic } \\
\text { acid, antigen, or antibody) } \\
\text { during admission or in the } \\
\text { previous } 12 \mathrm{wk}\end{array}$ & $\begin{array}{l}\text { Positive for current or recent } \\
\text { SARS-CoV-2 infection by RT-PCR, } \\
\text { serology or antigen test, or } \\
\text { exposure to a suspected or } \\
\text { confirmed COVID-19 case within } \\
4 \text { wk before onset of symptoms }\end{array}$ & NA \\
\hline
\end{tabular}

Note: $\mathrm{AHA}=$ American Heart Association, $\mathrm{CDC}=$ Centers for Disease Control and Prevention, $\mathrm{CRP}=\mathrm{C}$-reactive protein, $\mathrm{ESR}=$ erythrocyte sedimentation rate, $\mathrm{hpf}=$ high power field, IL-6 = interleukin 6, NA = not applicable, RT-PCR = reverse transcription-polymerase chain reaction.

*Erythema and edema of the hands and feet in acute phase or periungual desquamation in subacute phase, or both.

†Maculopapular, diffuse erythroderma or erythema multiforme-like.

‡Bilateral bulbar conjunctival injection without exudate.

$\S$ Erythema and cracking of lips, strawberry tongue, or erythema of oral and pharyngeal mucosa.

Many questions about MIS-A remain unanswered. Our patient did not present with the more commonly reported symptoms of stroke, shock or cardiac dysfunction requiring management in the intensive care unit. ${ }^{4}$ This may be explained by our patient having a milder spectrum illness or by the prompt diagnosis and interventions he received. Several features of our patient's presentation raised early concern for
MIS-A or a Kawasaki-like illness. Our patient met the diagnostic criteria for complete Kawasaki disease $5 \mathrm{~d}$ of fever and 4 out of 5 clinical features: extremity changes, conjunctivitis, oral changes and cervical lymphadenopathy; our patient did not have a rash) and MIS-C (except for age). However, evidence of recent SARS-CoV-2 infection and the age of the patient made MIS-A more likely as the cause. 


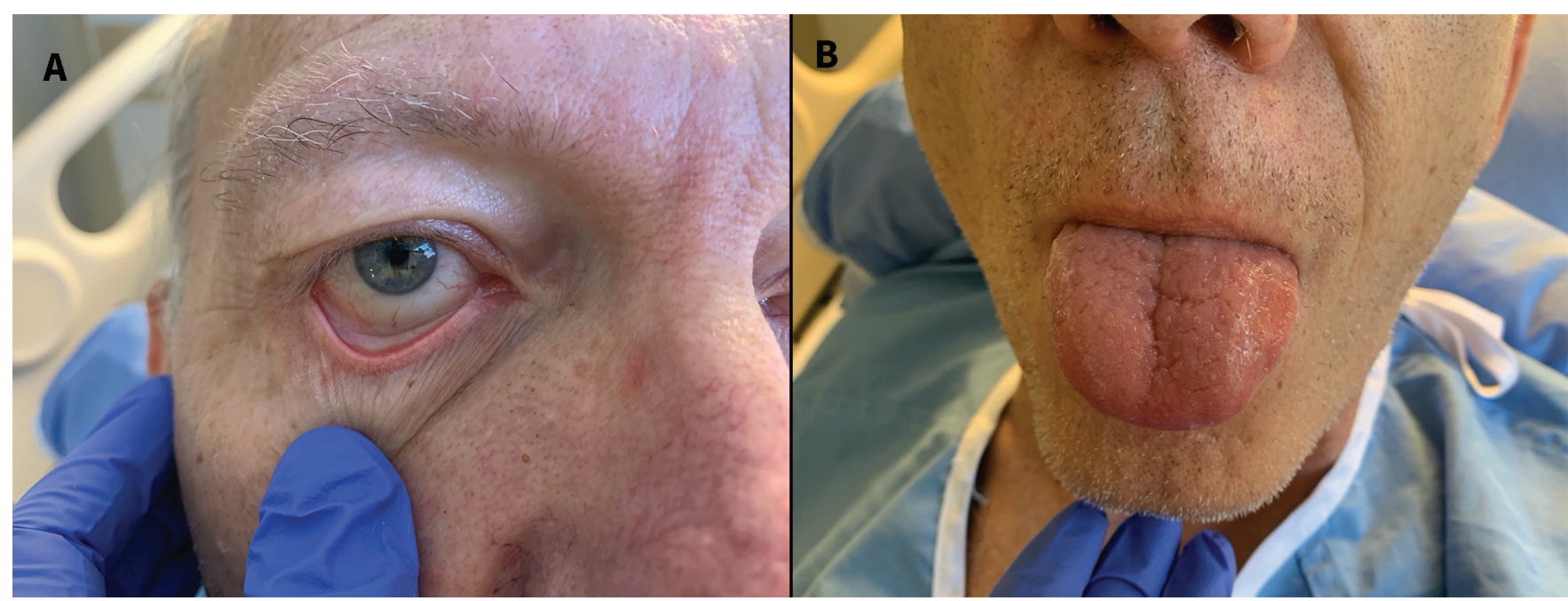

Figure 3: Near-complete resolution of the patient's conjunctivitis $(A)$ and improvement in glossitis, and near-complete resolution of enanthem of the tongue (B) on day 1 after initiation of high-dose steroids.

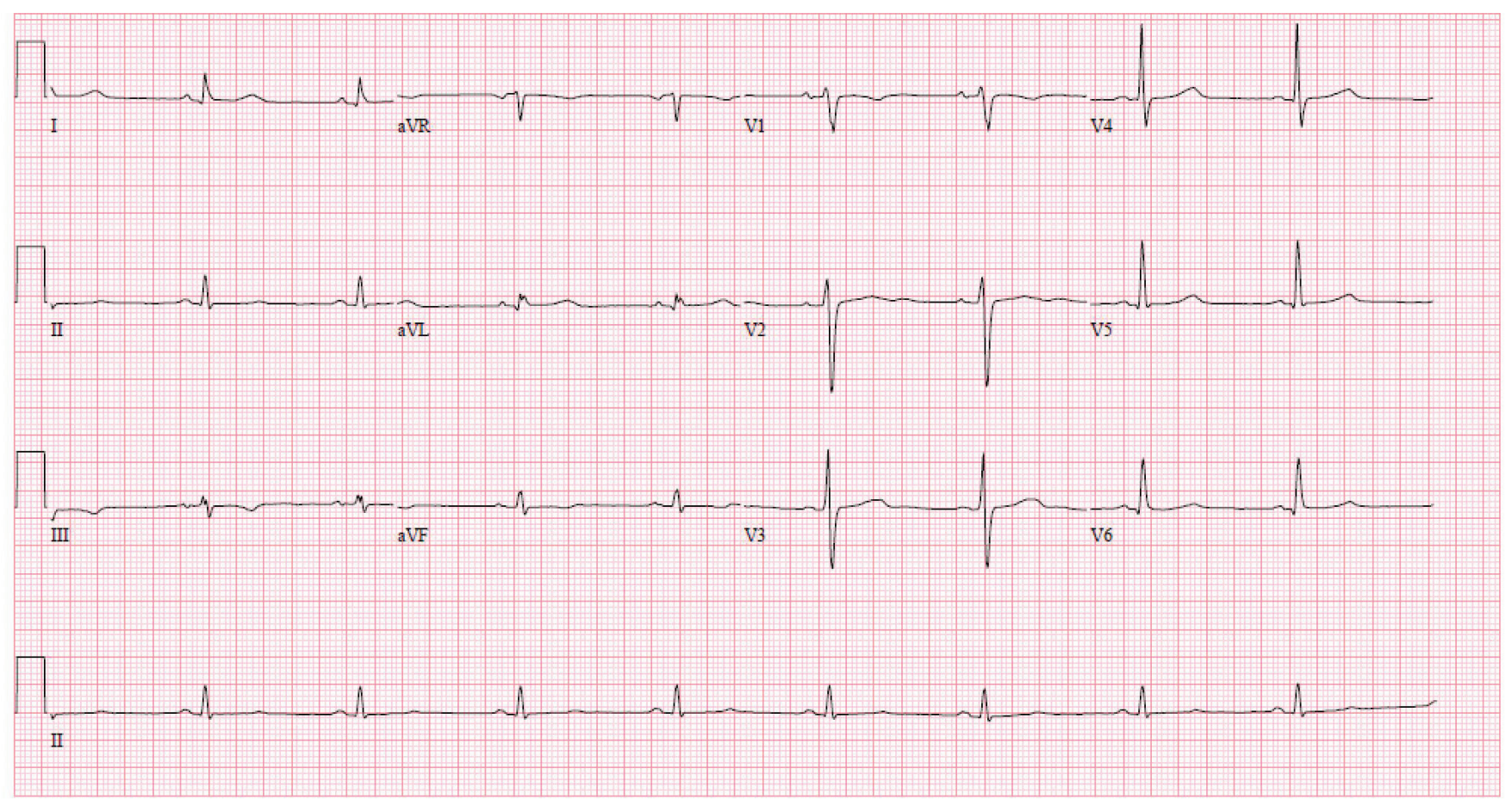

Figure 4: Sinus bradycardia of 54 beats/min and otherwise normal electrocardiogram with resolution of atrial fibrillation and ST-T changes prior to discharge.

The American College of Rheumatology published a review comparing and contrasting features between MIS-C and Kawasaki disease, and it reported that about $25 \%-50 \%$ of patients who fulfilled criteria for MIS-C also met the full diagnostic criteria for Kawasaki disease. ${ }^{11}$ Two differences between the conditions were ethnic distribution (highest among people of Japanese descent in patients with Kawasaki disease) and age distribution (usually younger than $5 \mathrm{yr}$ for Kawasaki disease, and a broader range, from 3 months to $21 \mathrm{yr}$, for MIS-C).,211,12

Standardized treatment for MIS-A is yet to be established. Our patient improved with 3 days of methylprednisolone $125 \mathrm{mg} / \mathrm{d}$, then an oral prednisone taper of $50 \mathrm{mg} / \mathrm{d}$ for 3 days, followed by a tapering dose decreasing by $10 \mathrm{mg} / \mathrm{d}$ every 3 days until he was weaned off steroids (for a total oral course of $15 \mathrm{~d}$ ). He received IV immunoglobulin $1 \mathrm{~g} / \mathrm{kg} / \mathrm{d}$ for 2 days and oral ASA $325 \mathrm{mg} / \mathrm{d}$ until clinical resolution, as evidenced by absence of fevers and normal C-reactive protein. This treatment was based on expert opinion and up-to-date evidence on Kawasaki disease and MIS-C., 2,6,8,11-13 The American College of Rheumatology recommends a step-wise approach to immunomodulatory treatment in MIS-C with IV immunoglobulin or glucocorticoids considered as first-tier agents, ${ }^{11}$ and the American Heart Association recommends high-dose 
immunoglobulin $(2 \mathrm{~g} / \mathrm{kg}$ ) as a single IV dose for treatment of Kawasaki disease. ${ }^{2}$ Although the patient did not have clinically significant thrombocytosis, we prescribed a short course of high-dose ASA to prevent thrombosis and coronary artery aneurysms. ${ }^{11}$

The optimal follow-up for MIS-A is currently unknown, but experts support monitoring for coronary artery dilatation and aneurysm, as with MIS-C- or Kawasaki-like illness. ${ }^{2,11}$ Unlike in children, for whom echocardiography is the imaging choice for coronary artery diameter, the visualization of coronary arteries becomes progressively more difficult as body size increases, making CT coronary angiography preferred for surveillance in adults. ${ }^{2}$ Our patient's coronary angiogram showed triple-vessel coronary artery disease without clinically important stenosis and no coronary aneurysms or findings suggestive of coronary artery vasculitis. At time of writing, a repeat CT to visualize coronary artery calibre is still pending for 6 months after discharge.

Unlike for MIS-C, there is currently no requirement to report cases of MIS-A to provincial or state authorities, but this should be encouraged to facilitate research and improve patient outcomes. ${ }^{6}$

\section{References}

1. Ontario Agency for Health Protection and Promotion (Public Health Ontario). An overview of cycle threshold values and their role in SARS-CoV-2 real-time PCR test interpretation. Toronto: Queen's Printer for Ontario; 2020. Available: www.publichealthontario.ca/-/media/documents/ncov/main/2020/09/cycle -threshold-values-sars-cov2-pcr.pdf?la=en (accessed 2021 May 11).

2. McCrindle BW, Rowley AH, Newburger JW, et al.; American Heart Association Rheumatic Fever, Endocarditis, and Kawasaki Disease Committee of the Council on Cardiovascular Disease in the Young; Council on Cardiovascular and Stroke Nursing; Council on Cardiovascular Surgery and Anesthesia; Council on Epidemiology and Prevention. Diagnosis, treatment, and long-term management of Kawasaki disease: a scientific statement for health professionals from the American Heart Association. Circulation 2017;135:e927-99.

3. National Center for Immunization and Respiratory Diseases (NCIRD). Information for healthcare providers about multisystem inflammatory syndrome in children (MIS-C). Atlanta: Centers for Disease Control and Prevention; reviewed 2021 Feb. 17. Available: https://www.cdc.gov/mis-c/hcp/\#: :text=Case\%20Definition\%20for\%20 MIS\%2DC\&text=No\%20alternative\%20plausible\%20diagnoses\%3B\%20AND,to\%20 the $\% 20$ onset $\% 20$ of\%20symptoms (accessed 2021 Jan. 13).

4. Morris SB, Schwartz NG, Patel P, et al. Case series of multisystem inflammatory syndrome in adults associated with SARS-CoV-2 Infection - United Kingdom and United States, March-August 2020. MMWR Morb Mortal Wkly Rep 2020;69: 1450-6.

5. Complications. In: BMJ Best Practice: Coronavirus diseases 2019 (COVID-19). London (UK): BMJ; 2021. Available: bestpractice.bmj.com/topics/en-us /3000168/pdf/3000168/Coronavirus\%20disease\%202019\%20\%28COVID-19\%29. pdf (accessed 2021 Jan. 11).

6. Cheung EW, Zachariah P, Gorelik M, et al. Multisystem inflammatory syndrome related to COVID-19 in previously healthy children and adolescents in New York City. JAMA 2020;324:294-6.

7. National Center for Immunization and Respiratory Diseases (NCIRD). Health department-reported cases of multisystem inflammatory syndrome in children (MIS-C) in the United States. Atlanta: Centers for Disease Control and Prevention; reviewed 2021 May 11. Available: https://www.cdc.gov/mis-c/cases/index.html (accessed 2021 Jan. 10).
8. Kofman AD, Sizemore EK, Detelich JF, et al. A young adult with COVID-19 and multisystem inflammatory syndrome in children (MIS-C)-like illness: a case report. BMC Infect Dis 2020;20:716.

9. Shaigany S, Gnirke M, Guttmann A, et al. An adult with Kawasaki-like multisystem inflammatory syndrome associated with COVID-19. Lancet 2020;396:e8-10.

10. Ahsan T, Rani B. A case of multisystem inflammatory syndrome post-COVID-19 infection in an adult. Cureus 2020;12:e11961.

11. Henderson LA, Canna SW, Friedman KG, et al. American College of Rheumatology clinical guidance for multisystem inflammatory syndrome in children associated with SARS-CoV-2 and hyperinflammation in pediatric COVID-19: version 1. Arthritis Rheumatol 2020;72:1791-805.

12. Gomard-Mennesson E, Landron C, Dauphin C, et al. Kawasaki disease in adults: report of 10 cases. Medicine (Baltimore) 2010;89:149-58.

13. Tam H, El Tal T, Go E, et al. Pediatric inflammatory multisystem syndrome temporally associated with COVID-19: a spectrum of diseases with many names. CMAJ 2020;192:E1093-6.

\section{Competing interests: None declared.}

This article has been peer reviewed.

The authors have obtained patient consent.

Affiliation: Division of Infectious Diseases, Department of Medicine, Cumming School of Medicine, University of Calgary, Calgary, Alta.

Contributors: Both authors contributed to the conception and design of the work, drafted the manuscript, revised it critically for important intellectual content, gave final approval of the version to be published and agreed to be accountable for all aspects of the work.

Content licence: This is an Open Access article distributed in accordance with the terms of the Creative Commons Attribution (CC BYNC-ND 4.0) licence, which permits use, distribution and reproduction in any medium, provided that the original publication is properly cited, the use is noncommercial (i.e., research or educational use), and no modifications or adaptations are made. See: https://creativecommons.org/licenses/by-nc-nd/4.0/

Acknowledgements: The authors acknowledge Drs. Glen Hazlewood, Heinrike Schmeling and Kevin Fonseca for their expert opinion in the management of this case.

Correspondence to: Geneviève Kerkerian, genevieve.kerkerian@albertahealthservices.ca

The section Cases presents brief case reports that convey clear, practical lessons. Preference is given to common presentations of important rare conditions, and important unusual presentations of common problems. Articles start with a case presentation (500 words maximum), and a discussion of the underlying condition follows (1000 words maximum). Visual elements (e.g., tables of the differential diagnosis, clinical features or diagnostic approach) are encouraged. Consent from patients for publication of their story is a necessity. See information for authors at www.cmaj.ca. 